\title{
The Impact of Publicly Owned Hotels on Competing Properties
}

Cornell Hospitality Quarterly

2016, Vol. 57(4) 348-366

(C) The Author(s) 2015

Reprints and permissions:

sagepub.com/journalsPermissions.nav DOI: $10.1177 / 1938965515615686$

cqx.sagepub.com

\author{
Robert R. Nelson', Jan A. deRoos², and Andrey D. Ukhov²
}

\begin{abstract}
Substantial public subsidies, and even outright public ownership, of hotels have become common in the United States as communities target tourism as an integral economic development tool. A critical question that is increasingly being raised about the public sector entering the hotel business is, are these government-funded facilities unfair competition to properties developed by the private sector? The common reply to these concerns is that the publicly owned hotel is critical to growing demand for lodging accommodation and that once it opens, the new hotel will attract enough new business that all hotels will benefit. We use an event study to test this hypothesis across all of the $100 \%$ publicly developed hotels for which there are sufficient data to conduct the analysis. In looking at these 21 hotels, we found strong evidence that the performance of neighboring hotels worsens after the introduction of a publicly owned hotel.
\end{abstract}

\section{Keywords}

convention hotels; public-private partnership; impact study; public subsidies

The use of various public subsidies and financing to encourage hotel development has become widespread in the United States. ${ }^{1}$ Known generically as public-private partnerships, we refer to public-private partnerships involving lodging facilities as publicly subsidized hotels or PSHs. At the far end of the subsidy spectrum are those hotels that are owned outright by the public, that is, they are funded and owned by a public authority; we call these hotels publicly owned hotels or POHs.

The use of public money to either develop in entirety or assist the development of a hotel raises many questions. This study focuses on one question that is increasingly getting attention and in some cases inspiring lawsuits (Edwards vs. Erie County; Milford \& Montgomery, 2011; Mirabella, 2005); that is, how are neighboring hotels affected when they have new publicly subsidized competition? There are two opposing camps that frequently square off in such debates. Those in favor of the $\mathrm{POH}$ use a positive externalities argument to claim that the $\mathrm{POH}$ is a needed "game changer" that will benefit the community by enabling it to attract convention and other visitors who otherwise would not come without this additional room inventory. These new visitors increase spending, employment, and tax revenues.

Among the counter veining arguments is that real estate speculation in the form of hotel developments is an inappropriate role for government. Not only is hotel development a risky venture, but $\mathrm{POHs}$ are also unfair competition that can undermine private sector investments by introducing non-price competition that can hurt neighboring hotels. ${ }^{2}$
Proponents of POHs counter that these public investments will actually help existing hotels in two ways: First, the new hotel will be a price leader that will elevate prices (Average Daily Rate or ADR) for surrounding hotels, second, the new hotel will induce demand in a market and attract enough new business to create spillover effects that benefit surrounding hotels. ${ }^{3}$

\section{The Impact of POHs on Competing Properties}

Despite the importance of how such a property might affect other hotels in the market, there is little in the academic literature to guide policymakers on this issue. Our study is a step toward bridging this gap. In this study, we identified 33 hotels owned outright by the public; a not-for-profit corporation or other agency of the sponsoring government generally holds the title of the hotel and is responsible for engaging the hotel developer and operator (Hazinski, 2004). We use an event study methodology, asking whether performance of hotels competitive with the $\mathrm{POH}$ changes after its

'Department of Hotel, Restaurant and Institutional Management, University of Delaware, Newark, DE, USA

${ }^{2}$ School of Hotel Administration, Cornell University, Ithaca, NY, USA

Corresponding Author:

Robert R. Nelson, Raub Hall, Department of Hotel, Restaurant and Institutional Management, University of Delaware, Newark, DE 19716 USA.

Email: bnelson@udel.edu 
introduction, the "event." The research question is salient, and is being raised in many communities. We could provide dozens of similar quotes from across the country, but this one from Minneapolis regarding a proposed subsidy for a hotel to support their convention center is typical:

Minneapolis officials have lobbied on and off for a convention hotel several times in recent years, saying that such a property is needed in order to compete with markets like Denver and Indianapolis for large, national meetings and conventions. Opponents, however, say that a 1,000-room hotel would be a bad use of public money and would hurt existing hotels by flooding the market with additional rooms and creating unfair competition. (Vonmhof, 2013)

With very few exceptions, we find that the POHs harm the top line operating metrics of the hotels in the competitive set. Our empirical results suggest that introduction of a $\mathrm{POH}$ to the market is followed by deterioration of key performance metrics of hotels that are directly competitive with the POH: ADRs decline, occupancies (OCC) fall, and revenues per available room (RevPAR) decrease. Not only do the levels of performance metrics decline but also often volatility increases significantly as well. The results do not corroborate the frequently told story of the rising tide that lifts all boats. This has policy implications for those considering public ownership or subsidies to encourage the development of hotels.

\section{Theory and Literature Review}

It is widely accepted that the use of public funds to create, operate, and maintain a city's convention center and associated infrastructure is a legitimate public activity due to the positive externalities created by the convention center. ${ }^{4}$ The classic public finance argument is that while the convention center itself may be an economically marginal business activity, it creates positive economic activity in the community that cannot be captured by the center; thus, the convention center should be a publicly owned or publicly subsidized venue. The use of public finance has been extended to include headquarters hotels located adjacent to convention centers as the private market perceives these projects as difficult, if not impossible, to finance without the use of public funding or subsidy., ${ }^{5,6}$ In recent years, many communities made tourism development a part of their overall local economic development strategy and extended subsidies beyond convention hotels to other types of lodging.

Public finance theory provides well-established tools to deal with externalities when private markets fail to account for the benefits or costs of economic activity. The classic policy prescriptions are to tax negative externalities (e.g., air or water pollution) and to subsidize positive externalities (museums, libraries, sporting venues, convention centers). Stiglitz (1988) and Rosen and Gayer (2008) show that subsidies can help to provide more optimal provision of public goods than relying on the private sector. Stiglitz (1988) uses the example of tax credits for the restoration of historic buildings as an example of a public subsidy to encourage positive externalities. Rosen and Gayer (2008) provide the same policy prescription, which they call a "Pigovian subsidy," but caution policymakers on its use (p. 101). ${ }^{7}$ Bartik (1990, 2005) cites numerous market failures that call for a unified policy prescription including the localization of subsidies most likely to produce the most good. ${ }^{8}$

For reasons discussed in Harberger (1974), the estimation of the overall welfare effects of government interventions to correct externalities is more challenging than first outlined by Pigou (1932) in the classical welfare economics treatment. In the presence of unpriced externalities, policies aimed to correct an externality via subsidy can potentially exacerbate other distortions in related markets. Theory alone cannot shed light on the relative importance of the primary welfare effect of a given policy (defined by the welfare gain from correcting the externality addressed by the policy) and the interaction effects (defined as welfare effects that result from the interaction of the new policy with other related markets; Bento, Kaffine, Roth, and Zaragoza-Watkins, 2014). An empirical investigation is needed to evaluate a particular subsidy.

In the tourism sector of the economy, there is an extensive literature on the use of public subsidy, its success, and failures. Choy (1991) and Fenich (1992) provide early examples of the discussion; Choy focuses on the macroeconomic impacts of planning tourism destinations while Fenich is focused on convention centers and their impacts, both positive and negative on the urban landscape. Tsukahara (1995) develops a theoretical model showing that "optional public services" such as museums or stadiums are provided by the public when "their cost is 'small' relative to the cost of essential public services." Dwyer, Forsyth, and Spurr (2004) note the extensive use of public funds in the tourism sector and critique the tools that economists and policymakers use to analyze the economic impact of tourism and tourism policy. Judd's (2003) compendium has entire chapters devoted to the public and private nature of cities and the use of public finance to transform urban cores in both positive and negative ways. ${ }^{9}$ Bernini and Pellegrini $(2011,2013)$ examine the impact of public subsidy on private tourism firms funded under a regional policy in Italy, a unique laboratory. In both studies, they report positive employment growth and output but a decrease in productivity for subsidized firms. Rosentraub and Joo (2009) examine the relative returns to public investment in tourist amenities. They find that investments in sports and amusements produced the most significant gains for regions, recognizing the importance of public investment to stimulate investment. ${ }^{10}$ Schwester (2007) examines public investment in athletic venues with a literature review that 
shows insignificant job creation, insignificant changes in local spending, and insignificant increases in per capita incomes from investments in sporting venues.

At the same time, much less work is explicitly focused on the hotel industry. Blocher (2006) notes that "(d)espite the massive public investment in hotel projects, surprisingly little scholarly literature addresses the wisdom of this public support" (p. 139). Boo and Kim (2010) find that it is the size of the function space in a convention center that is positively associated with hotel stays, not the number of show days or attendance. Clark's (2007) Delphi study found that a headquarters hotel is an amenity necessary for a convention center to meet its potential. He goes on to note that the subsidies necessary to bring such a hotel to the market are an additional cost that many communities do not consider when they build a convention center. Detlefsen (2012) suggests that open bidding processes should be used to minimize the public subsidies necessary to bring convention hotels to market. Gee and Singh (2008) provide some nonquantitative guidelines that governments can use when considering subsidies to encourage hotel development, noting that ". . . in most instances, government officials have limited knowledge of the relative costs and benefits of using investment incentives" (p. 142). Hazinski (2010) proposes using regression models to look at the impacts that the opening of a convention center has on the metrics of the local hotel market, but does not empirically test the model.

Among those who have questioned the wisdom of public support for hotels are Sanders (1999, 2004a, 2004b, 2005a, 2005b, 2014) and Laslo and Judd (2005) who question the use of public funding for convention centers and hotels, criticizing the practice as being insulated from democratic processes while chronicling decades of publicly supported hotels that do not live up to their expected financial returns. Walker (2003) provides evidence that the opening of convention hotels does not generate additional measureable demand. Murphy (2005) provides a critical review of feasibility studies done on PSHs claiming that they are frequently overly optimistic about expected performance. Nelson (2006) proposes processes to review feasibility studies for PSHs and describes political barriers that make such analyses rare.

\section{Data and Method}

For this study, we begin with the universe of 33 known POHs in the United States as of 2014. This list was reduced to eliminate properties that had been open for less than 4 years as the event study methodology requires 4 years of post-opening data to examine the short- and longer-term impacts of the $\mathrm{POH}$ openings on the competitive hotels. O'Neill (2011) shows that the mean stabilization period for all hotel types is 3.08 years, while Hazinski (2004) speaks directly to the matter, referencing a 3- to 4-year stabilization period for a $\mathrm{POH}$ during which ". . . the occupancy and
ADR of existing hotels is expected to decline somewhat. As the new hotel reaches stabilization and generates additional room night demand, the occupancy and ADR of competitive hotel properties are expected to return to normal levels" (p. 7). Two POHs, the Trenton Marriott at Lafayette Yard ${ }^{11}$ and Hilton Austin Airport, were not included because they had no competitive hotels in the markets in which they were built. The reductions resulted in $21 \mathrm{POHs}$ and hotel markets that are examined in this study.

Our analysis explores how the opening of a $\mathrm{POH}$ affects the performance of hotels that are directly competitive with the $\mathrm{POH}$. In the hotel industry, these competing hotels are known as the "competitive set." Monthly operating data for each competitive set were obtained from STR Global. The hotels used to create the competitive set are those hotels identified as the primary competitors by each of the $\mathrm{POH}$ hotel's management team. These competitive sets were verified as accurate by STR Analytics, a unit of STR Global. In no case did STR Analytics find that the competitive set used by the $\mathrm{POH}$ management team was inappropriate. ${ }^{12}$ To be clear, this study does not analyze other impacts of POHs beyond their impact on the competitive set, such as the direct tax benefits, employment, and other positive externalities.

The performance metrics used in this study are the monthly averages for the ADR, OCC percentage, and the RevPAR for each competitive set. Data for each competitive set include 24 months prior to opening of the $\mathrm{POH}$ and 48 months after the opening of the POH. ${ }^{13}$ STR Global provides data for the competitive set as if it were a single hotel; no individual hotel data are available.

Next, the metrics for each competitive set were indexed to the same metrics for the entire U.S. market. Travel and hotel performance are greatly influenced by the health of the economy. To identify whether the changes in the performance metrics were the result of the new $\mathrm{POH}$ entering the local market or the result of larger trends in the economy, the data for each competitive set were indexed to the performance of the entire U.S. hotel market using the U.S. national data from the STR Global database. The index is the ratio of a given competitive set metric (e.g., RevPAR) to the national data on the metric (in this case, RevPAR). For example, in a month, in which a competitive set's occupancy is $77 \%$ and the national occupancy is $70 \%$, the index is $0.77 / 0.70=$ 1.10 ; that is, the competitive set's occupancy is $110 \%$ of the national occupancy. Similarly, RevPAR index of 1.20 means that the competitive set is $20 \%$ better than the U.S. market, whereas a RevPAR index of 0.75 means that the competitive set is $25 \%$ worse than the U.S. market. Indexing the competitive set's performance to that of the entire United States, adjusts for the impacts of overall economic conditions (recessions, inflation, and events such as September 11, 2001) on the performance metrics and thus better isolate the impact of the $\mathrm{POH}$ opening on the competitive set. 
Our null hypotheses are that there is no impact on the market due to the opening of a $\mathrm{POH}$.

$$
\begin{gathered}
\mathrm{H}_{\mathrm{O} 1}: \text { RevPAR-Index } \text { pre-event }=\text { RevPAR-Index }_{\text {post-event }} . \\
\mathrm{H}_{\mathrm{O} 2}: \text { ADR-Index } \\
\mathrm{H}_{\mathrm{O} 3 \mathrm{e}-\mathrm{event}}: \text { OCC-Index } \\
\text { pre-event }
\end{gathered}
$$

If the POHs produce positive externalities for the hotel market, the alternative hypothesis is that there is a positive impact from the opening of a $\mathrm{POH}$.

$$
\begin{gathered}
\mathrm{H}_{\mathrm{A} 1}: \text { RevPAR-Index } \text { pre-event }<\text { RevPAR-Index } \text { post-event } \\
\mathrm{H}_{\mathrm{A} 2}: \text { ADR-Index } \text { pre-event }<\text { ADR-Index } \text { post-event } . \\
\mathrm{H}_{\mathrm{A} 3}: \text { OCC-Index } \text { pre-event }<\text { OCC-Index }_{\text {post-event }} .
\end{gathered}
$$

However, if the $\mathrm{POH}$ does not produce positive externalities for the hotel market, the $\mathrm{POH}$ takes customers from competing hotels, and the alternative hypothesis is that the opening of a $\mathrm{POH}$ damages their performance.

$$
\begin{gathered}
\mathrm{H}_{\mathrm{B} 1}: \text { RevPAR-Index } \text { pre-event }>\mathrm{RevPAR}_{\mathrm{B}} \text { Index } \text { post-event } . \\
\mathrm{H}_{\mathrm{B} 2} \text { ADR-Index } \text { pre-event }>\text { ADR-Index } \text { post-event } . \\
\mathrm{H}_{\mathrm{B} 3}: \text { OCC-Index } \text { pre-event }>\text { OCC-Index }_{\text {post-event }} .
\end{gathered}
$$

The hypotheses are tested on the indexes for three performance metrics using a combination of univariate and multivariate methods to explore the hypotheses, allowing for a very flexible specification to estimate the impact. We also test for market volatility by examining the change in variability of the metrics by testing the difference in the variance of the competitive set index pre- and post-opening of a $\mathrm{POH}$.

\section{Results}

\section{Summary Statistics}

The 21 POHs and their markets are listed in Table 1. The sample includes $\mathrm{POH}$ properties in different states, developed between 1993 and 2009. Descriptive statistics for the 21 competitive sets are given in Table 2 , showing the values of the RevPAR, ADR, and OCC indexes prior to the opening of the $\mathrm{POH}$.

Indices for each market were plotted over time to visualize the data and trends before performing more rigorous parametric analyses. We provide an example in Figure 1, which is a plot of the RevPAR index for the Baltimore market. Note the clearly identifiable trend in the data: The average level of RevPAR index is higher before opening of the $\mathrm{POH}$. The data also show the classic inter-year seasonality of lodging markets, a characteristic of the data that we take into account in the multivariate statistical tests.

\section{Results of Univariate Tests}

We look first at the summary statistics for the entire sample, and then examine the summary statistics for each of the 21 competitive sets. In all cases, the "event" is the opening of the $\mathrm{POH}$. The event month is excluded from the analysis. In each case, there are 24 months of data prior to the event and 48 months of data after the event. The whole sample (pooled for all 21 competitive sets) results are as follows:

Table 3 shows that all three metrics point to a statistically significant deterioration in the aggregate performance of the competitive sets after the opening of the POHs. These results lend support to rejecting the null hypothesis of no impact, rejecting the alternative hypothesis of positive externalities, and accepting the alternative hypothesis of damage to the competing hotels. However, the unconditional means do not control for autocorrelation and seasonality in the data, nor do they control for market improvement over time. We control for these factors using a maximum likelihood methodology that is presented in the following section.

We next turn our attention to the individual markets and whether the introduction of a POH had an impact locally. Table 4 summarizes the results for all 21 individual markets, whereas Table 5 contains the detailed results for each market.

The left panel of Table 4 shows that the performance metrics are inconclusive for RevPAR in 13 markets, inconclusive for ADR in 8 markets, and inconclusive for OCC in 10 markets. In those cases where the results are statistically significant, the evidence points overwhelmingly to deteriorating performance; eight declines and no advances for RevPAR, nine declines and four advances for ADR, and eight declines and three advances for OCC. The panel on the right of Table 4 summarizes the results for the volatility tests: the left column is based on the $F$ Test and the right column is based on the Levene's Test. For the most part, the results are inconclusive, although ADR shows a statistically significant result in the majority of markets. For those markets where the results are statistically significant, the evidence points to a worsening in volatility with the greatest impact on ADR, where three markets are less volatile and at least eight markets are more volatile. No market showed a statistically significant drop in volatility for OCC, whereas five markets showed an increase. Finally, at least four markets have higher RevPAR volatility, and no more than two have lower RevPAR volatility. 


\section{Exhibit 1:}

Publicly Owned Hotels and Their Competitive Sets.

\begin{tabular}{|c|c|c|c|c|}
\hline City/municipality & Property name & $\begin{array}{l}\text { Opening year } \\
\text { and month }\end{array}$ & $\begin{array}{l}\text { Property } \\
\text { room count }\end{array}$ & $\begin{array}{l}\text { Hotels/rooms in } \\
\text { competitive set }\end{array}$ \\
\hline Austin, TX & Hilton Austin & 2004, January & 800 & $4 / 1,440$ \\
\hline Baltimore, MD & Hilton Baltimore & 2009, August & 757 & $6 / 3,044$ \\
\hline Chicago, IL & Hyatt Regency McCormick Place & 1998, June & 800 & $4 / 5,954$ \\
\hline Coralville, IA & Marriott-Coralville & 2006, August & 280 & $5 / 602$ \\
\hline Dallas, TX & Grand Hyatt Dallas Fort Worth & 2005, July & 298 & $7 / 3,246$ \\
\hline Denver, CO & $\begin{array}{l}\text { Hyatt Regency Denver at Colorado } \\
\text { Convention Center }\end{array}$ & 2005, December & 1,100 & $4 / 2,790$ \\
\hline Erie, PA & Sheraton Erie Bayfront Hotel & 2008, April & 203 & $5 / 633$ \\
\hline Lombard, IL & Westin Lombard Yorktown Center & 2007, August & 500 & $6 / 1,917$ \\
\hline Midwest City, OK & $\begin{array}{l}\text { Sheraton Midwest City Hotel at the Reed } \\
\text { Conference Center }\end{array}$ & 2006, February & 151 & $5 / 451$ \\
\hline Myrtle Beach, SC & $\begin{array}{l}\text { Sheraton Myrtle Beach Convention Center } \\
\text { Hotel (Opened as Radisson) }\end{array}$ & 2003, January & 404 & $4 / 1,568$ \\
\hline Omaha, NE & Hilton Omaha & 2004, April & 450 & $7 / 1,832$ \\
\hline Overland Park, KS & Sheraton Overland Park Hotel & 2002, December & 412 & $4 / I, \mid 43$ \\
\hline Phoenix, AZ & Sheraton Phoenix Downtown Hotel & 2008, September & 1,000 & $5 / 1,832$ \\
\hline Pittsburgh, PA & Hyatt Regency Pittsburgh International Airport & 2000 , June & 331 & $5 / 1,016$ \\
\hline Providence, RI & Omni Providence Hotel & 1993, December & 564 & $4 / 1,183$ \\
\hline Sacramento, CA & Sheraton Grand Sacramento Hotel & 200I, April & 500 & $4 / 1,642$ \\
\hline Schaumburg, IL & $\begin{array}{l}\text { Renaissance Schaumburg Convention Center } \\
\text { Hotel }\end{array}$ & 2006, July & 500 & $5 / 1,778$ \\
\hline Shreveport, LA & Hilton Shreveport & 2007, June & 313 & $7 / 1,090$ \\
\hline St. Louis, MO & Renaissance St. Louis Grand Hotel & 2003, April & $\mathrm{I}, 08 \mathrm{I}$ & $5 / 2,374$ \\
\hline Vancouver, WA & Hilton Vancouver Washington & 2005, June & 226 & $5 / 662$ \\
\hline Wayne County, MI & $\begin{array}{l}\text { Westin Detroit Metropolitan Airport (hotel } \\
\text { owned by Wayne County, MI) }\end{array}$ & 2002, December & 404 & $5 / I, 84 I$ \\
\hline Totals & & & 11,074 & $101 / 36,197$ \\
\hline
\end{tabular}

Note. The table shows each of the publicly owned hotels, its opening date, and room count. The last column indicates the number of hotels and the room count for the hotels considered as the competitive set to the publicly owned hotel. In this study, we examine the impact of the publicly owned hotels on the competitive sets.

Table 5 presents the results of the univariate tests on each market. The table is broken into three panels, one for RevPAR, one for ADR, and one for OCC. Within each panel, we report the percentage change in the mean value of the metric and the percentage change in the standard deviation of each metric after the opening of the $\mathrm{POH}$. We report the results of the $t$ test for the difference in the mean value of the metric before and after the event. We also report the results of an $F$ test and Levene's test for the equality of variance of the metric before and after the event. ${ }^{14}$

Overall results are as follows:

- For RevPAR, 17 of the 21 markets show a deterioration, with eight of the 17 being statistically significant at the $10 \%$ level or better. Four of the 21 markets show an improvement in RevPAR; none are statistically significant at the $10 \%$ level or better.

- Standard deviation shows an increase in 15 of the 21 markets for the monthly RevPAR, that is, these markets become more volatile. In five of the 15 cases, this increase in volatility is statistically significant at the $10 \%$ level or better. Six markets show a decrease in standard deviation of RevPAR; two of these are statistically significant at the $10 \%$ level or better.

- For ADR, 14 of the 21 markets show a deterioration, with nine of the 14 being statistically significant at the $10 \%$ level or better. Seven of the declines are larger than $10 \%$ in magnitude (all statistically significant at $1 \%$ level or better). Seven of the 21 markets show an improvement in ADR, with four of the seven being statistically significant at the $10 \%$ level or better.

- Standard deviation shows an increase in 17 of the 21 markets, with these markets becoming more volatile. In nine of the 17 cases, the increase in volatility is statistically significant at the $10 \%$ 


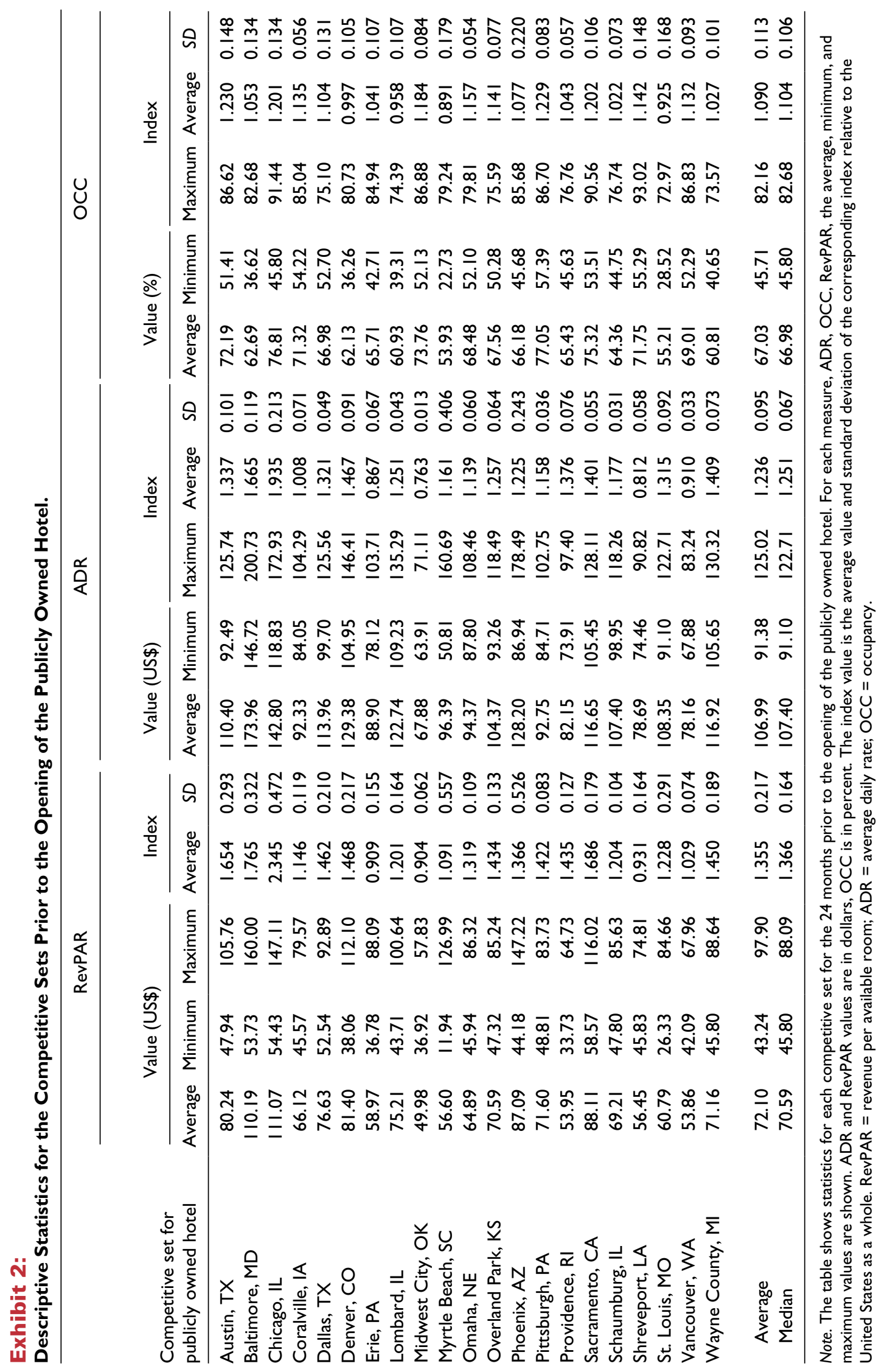




\section{Exhibit 3:}

RevPAR index plot for the Baltimore competitive set.

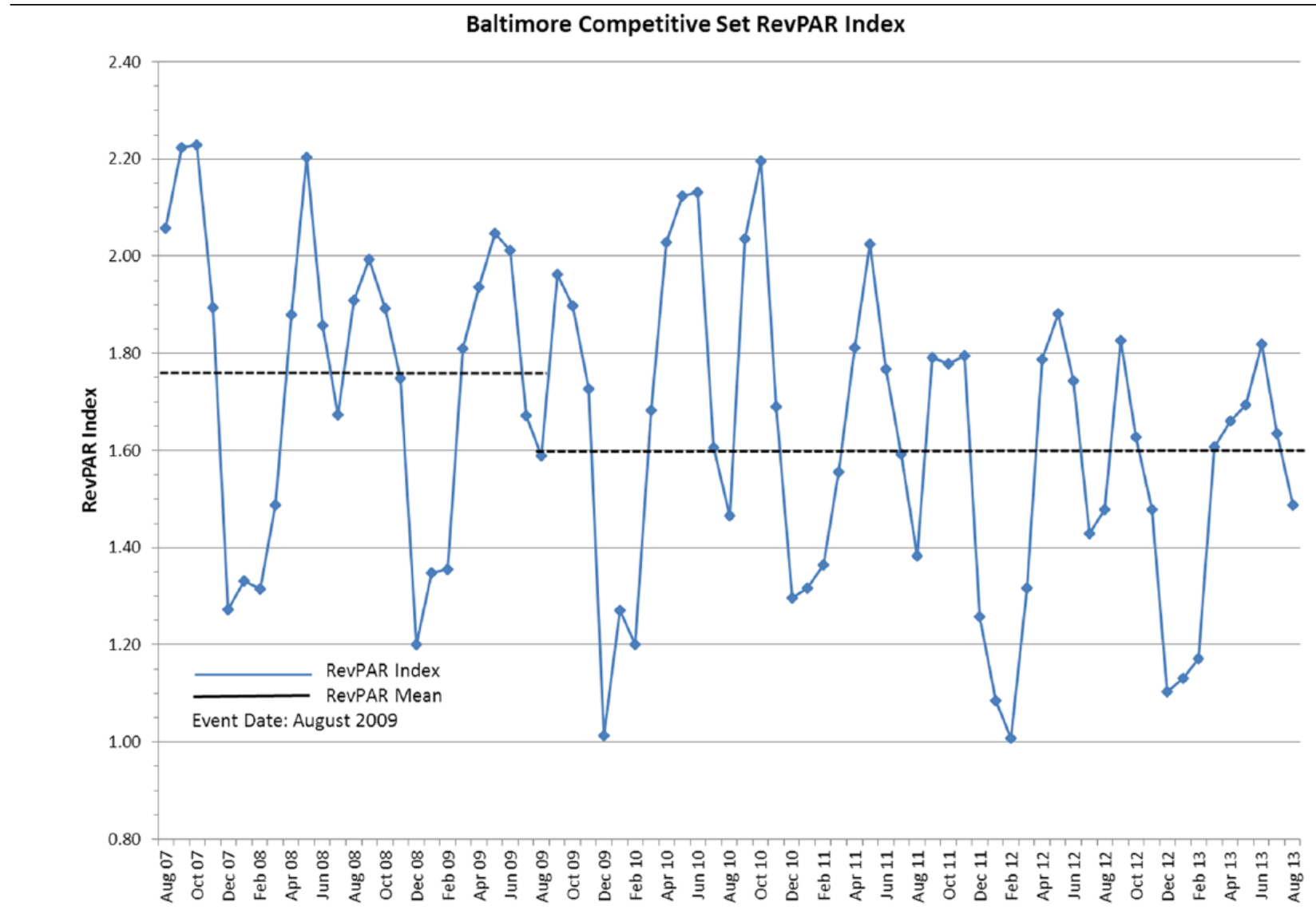

Note. The figure plots the monthly RevPAR index mean for the entire 72-month sample period. On the horizontal axis are the months representing the 24 months prior to and the 48 months after the opening of the Baltimore Hilton, a POH. The vertical axis is the RevPAR index for the competitive set of hotels, which is the monthly RevPAR for the Baltimore competitive set divided by the monthly RevPAR for the United States as a whole. An index value of I.0 means that the RevPAR for Baltimore was equal to the RevPAR for the United States as a whole. Also plotted are the before- and afterevent means for the index. One can see that the RevPAR index dropped after the opening of the POH. RevPAR = revenue per available room; $\mathrm{POH}=$ publicly owned hotel.

level or better. The remaining four markets show a decrease in standard deviation, three of these are statistically significant at the $10 \%$ level or better.

- For OCC, 16 of the 21 markets show a deterioration, with eight of the 16 being statistically significant at the $10 \%$ level or better. Five of the 21 markets show an improvement in occupancy, with three of the five being statistically significant at the $10 \%$ level or better.

- Standard deviation shows an increase in 11 of the 21 markets for OCC, with these markets become more volatile. In five of the 11 cases, this increase in volatility is statistically significant at the $10 \%$ level or better. Ten markets show a decrease in standard deviation, none of these are statistically significant at the $10 \%$ level or better.
Table 5 shows that not one market exhibits an increase in both ADR and OCC. Markets that show improvement in one metric uniformly show deterioration in the other metric. Another finding is that the whole sample and the individual market results show a greater impact on ADR than OCC, and one would have speculated that occupancy might suffer with the introduction of new supply, but the decline in pricing is more troublesome. The unconditional whole sample and the individual market results both indicate that the general trend is for a deterioration in the revenues (RevPAR) for the competitive sets. The results in some individual market do indicate some glimmers of hope, but in no case does a market exhibit an improvement in the mean and a reduction in the standard deviation for all three metrics. The competitive set in Midwest City, Iowa, does see a significant improvement in the ADR metrics (higher level of ADR and lower standard deviation), but this is not carried through to the RevPAR as this market was hurt by lower occupancies. 
Exhibit 4:

Pooled Whole Sample Results: Unconditional Test for Equal Means.

\begin{tabular}{lcccccc}
\hline $\begin{array}{l}\text { Measure of } \\
\text { performance }\end{array}$ & $\begin{array}{c}\text { Index mean prior } \\
\text { to POH opening }\end{array}$ & $\begin{array}{c}\text { Index mean after } \\
\text { POH opening }\end{array}$ & $\begin{array}{c}\text { Change } \\
\text { in mean }\end{array}$ & $\begin{array}{c}\text { Percentage } \\
\text { change }\end{array}$ & $\begin{array}{c}t \\
\text { statistic }\end{array}$ & $\begin{array}{c}p \\
\text { value }\end{array}$ \\
\hline RevPAR & 1.355 & 1.262 & -0.093 & -6.80 & 3.920 & .000 \\
ADR & 1.236 & 1.187 & -0.049 & -3.92 & 2.938 & .003 \\
OCC & 1.090 & 1.051 & -0.039 & -3.55 & 4.450 & .000 \\
\hline
\end{tabular}

Note. The table shows the unconditional mean of the competitive set indexes for the pooled sample in the 24 months prior to the opening of a POH and the 48 months after the opening of the $\mathrm{POH}$. The $t$ statistic is from a simple two-tailed "Chow-test" for equality of means with the appropriate adjustment for numbers of observations. $\mathrm{POH}=$ publicly owned hotel; RevPAR = revenue per available room; $A D R=$ average daily rate; $O C C=$ occupancy.

\section{Exhibit 5:}

Univariate Results Summary: Number of Changes in the Individual Competitive Sets.

\begin{tabular}{|c|c|c|c|c|c|c|c|c|c|}
\hline & \multicolumn{3}{|c|}{ Change in market performance } & \multicolumn{6}{|c|}{ Change in market volatility } \\
\hline & \multirow{2}{*}{$\begin{array}{c}\text { Improved } \\
\text { performance }\end{array}$} & \multirow{2}{*}{$\begin{array}{c}\text { Worse } \\
\text { performance }\end{array}$} & \multirow{2}{*}{$\begin{array}{c}\text { Not } \\
\text { statistically } \\
\text { significant }\end{array}$} & \multicolumn{2}{|c|}{ Markets less volatile } & \multicolumn{2}{|c|}{ Markets more volatile } & \multicolumn{2}{|c|}{$\begin{array}{l}\text { Not statistically } \\
\text { significant }\end{array}$} \\
\hline & & & & $F$ test & Levene's test & $F$ test & Levene's test & $F$ test & Levene's test \\
\hline RevPAR & 0 markets & 8 markets & 13 markets & 2 & I & 5 & 4 & 14 & 16 \\
\hline ADR & 4 markets & 9 markets & 8 markets & 3 & 3 & 9 & 8 & 9 & 10 \\
\hline OCC & 3 markets & 8 markets & 10 markets & 0 & 0 & 4 & 4 & 17 & 17 \\
\hline
\end{tabular}

Note. The count of statically significant market index changes out in the 21 competitive sets with POH introductions. For the counts on Market Volatility, the left column is based on the $F$ test and the right column is based on the Levene's test. RevPAR = revenue per available room; $\mathrm{ADR}=$ average daily rate; $\mathrm{OCC}=$ occupancy; $\mathrm{POH}=$ publicly owned hotel.

\section{Results From the Pooled Maximum Likelihood Model}

The whole sample univariate results are useful to establish an initial estimate of the impact of POHs on their competitive sets. Univariate results of the individual markets allow us to identify the impact in each market separately, albeit these tests are weaker in terms of statistical power when compared with the whole sample. The univariate tests, however, do not take into account certain statistical properties of the data, such as seasonality and autocorrelation. The performance metrics exhibit seasonality that is very different for different markets, the most obvious is winter performance for Sunbelt versus northern markets. Performance metrics may also have autocorrelation in the time series, a common property in business data. Autocorrelation, too, may be different for different markets. Finally, it is likely that a newly opened hotel might negatively affect a market when first introduced, but if $\mathrm{H}_{\mathrm{A}}$ is true, the market should quickly recover and show improved performance over time. To address these properties of the data and to control for them, a more detailed statistical analysis is needed. We proceed with this analysis using a pooled, maximum likelihood model. ${ }^{15}$

To rigorously assess the overall effect, we pool crosssection and time-series data. By pooling the data, we allow for flexibility in modeling market-specific effects for each competitive set. In other words, we build flexibility into our models to account for market-specific characteristics. The dependent variable is the index of performance (RevPAR, ADR, or OCC) for the competitive set for a given market. We estimate two models. In model 1 , the index is regressed on a market-specific intercept, estimated by $\alpha_{i} ; 11$ monthly dummies for each market to control for seasonality (January is omitted), estimated by $\lambda$; the post-event dummy variable, estimated by $\beta$; and a time dummy, estimated by $\mu$, to examine whether the post-event dummy variable changes over time. The post-event dummy variable takes the value of 1 in the 36 months following the opening of the $\mathrm{POH}$ in market $i$, and 0 otherwise; the long-term dummy takes the value of 1 in the fourth year (months 37-48) following the opening of the POH in market $i$. Model 1 is as follows:

$$
\begin{aligned}
& \text { Performance }_{i, t}=\alpha_{i}+\beta \text { PostEventDummy }_{i, t}+ \\
& \mu \text { LongTermDummy }_{i, t}+\sum_{k=1}^{11} \lambda_{k, i} \text { MonthDummy }_{k, i, t}+\varepsilon_{i, t}, \\
& \operatorname{Var}\left(\varepsilon_{i}\right)=\sigma_{i}^{2} .
\end{aligned}
$$

The subscript $i$ on the intercept $\alpha_{i}$ and on the coefficients for the 11 monthly dummy variables, $\lambda_{1, i}, \ldots \lambda_{11, i}$, indicates that these coefficients are specific to market $i$. 
Exhibit 6:

Univariate Results: Changes in the Performance Metrics and Variability for the Individual Competitive Sets.

\begin{tabular}{|c|c|c|c|c|c|c|c|c|c|c|c|c|c|c|c|}
\hline \multirow{2}{*}{$\begin{array}{l}\text { Competitive } \\
\text { set for publicly } \\
\text { owned hotel }\end{array}$} & \multicolumn{5}{|c|}{ RevPAR } & \multicolumn{5}{|c|}{ ADR } & \multicolumn{5}{|c|}{ OCC } \\
\hline & $\begin{array}{c}\% \\
\text { change }\end{array}$ & $\begin{array}{l}t \text { test } p \\
\text { value }\end{array}$ & $\begin{array}{c}\% \text { change } \\
\text { in } S D\end{array}$ & $\begin{array}{c}F \text { test } p \\
\text { value }\end{array}$ & $\begin{array}{l}\text { Levene } \\
p \text { value }\end{array}$ & $\begin{array}{c}\% \\
\text { change }\end{array}$ & $\begin{array}{l}t \text { test } p \\
\text { value }\end{array}$ & $\begin{array}{c}\% \text { change } \\
\text { in } S D\end{array}$ & $\begin{array}{c}F \text { test } p \\
\text { value }\end{array}$ & $\begin{array}{l}\text { Levene } \\
p \text { value }\end{array}$ & $\begin{array}{c}\% \\
\text { change }\end{array}$ & $\begin{array}{l}t \text { test } p \\
\text { value }\end{array}$ & $\begin{array}{c}\% \text { change } \\
\text { in } S D\end{array}$ & $\begin{array}{c}F \text { test } p \\
\text { value }\end{array}$ & $\begin{array}{l}\text { Levene } \\
p \text { value }\end{array}$ \\
\hline Austin & -8.00 & .275 & -1.20 & .457 & .897 & 6.00 & .057 & 33.90 & .066 & .08 & -11.00 & .003 & -8.10 & .305 & .528 \\
\hline Baltimore & -16.60 & .039 & -3.00 & .416 & .763 & -17.50 & .000 & 24.90 & .125 & .062 & 1.10 & .726 & -10.40 & .257 & .394 \\
\hline Chicago & 2.60 & .831 & 4.20 & .427 & .822 & 4.50 & .442 & 14.50 & .245 & .34 & -1.40 & .663 & -1.80 & .443 & .638 \\
\hline Coralville & -1.90 & .599 & 55.30 & .012 & .053 & -0.50 & .813 & 31.30 & .079 & .153 & -1.70 & .361 & 76.70 & .002 & .012 \\
\hline Dallas & 3.80 & .515 & 14.80 & .239 & .268 & 3.50 & .041 & 86.80 & .001 & .008 & -0.10 & .965 & -0.40 & .475 & .443 \\
\hline Denver & 6.60 & .308 & 25.10 & .124 & .244 & -2.50 & .352 & 26.00 & .116 & .301 & 6.00 & .043 & 14.80 & .239 & .52 \\
\hline Erie & -8.60 & .042 & 9.80 & .32 & .74 & -2.10 & .225 & 3.10 & .45 & .966 & -7.50 & .029 & 36.30 & .055 & .227 \\
\hline Lombard & -6.70 & .101 & -2.90 & .419 & .538 & -14.70 & .000 & 69.80 & .004 & .044 & 6.80 & .014 & 3.30 & .446 & .816 \\
\hline Midwest City & -0.90 & .648 & 43.80 & .031 & .117 & 1.30 & .026 & -12.70 & .000 & .000 & -3.30 & .13 & 5.60 & .399 & .467 \\
\hline Myrtle Beach & -0.70 & .964 & 13.30 & .263 & .425 & 1.50 & .887 & 6.20 & .386 & .695 & -3.20 & .519 & 13.30 & .263 & .279 \\
\hline Omaha & -11.50 & .000 & 9.60 & .322 & .73 & -4.10 & .014 & 10.90 & .301 & .986 & -6.20 & .000 & 13.90 & .254 & .328 \\
\hline Overland Park & -27.90 & .000 & -38.20 & .003 & .004 & -13.70 & .000 & -40.40 & .001 & .000 & -10.90 & .000 & -12.00 & .224 & .495 \\
\hline Phoenix & -6.80 & .609 & 1.40 & .486 & .75 & -1.60 & .793 & -2.70 & .425 & .844 & -4.40 & .463 & 10.90 & .301 & .361 \\
\hline Pittsburgh & -29.60 & .000 & 72.20 & .003 & .005 & -16.10 & .000 & 229.40 & .000 & .000 & -9.50 & .000 & 35.00 & .061 & .095 \\
\hline Providence & -5.70 & .13 & 45.10 & .028 & .037 & -10.80 & .000 & 38.90 & .045 & .084 & 4.40 & .023 & 86.50 & .001 & .012 \\
\hline Sacramento & -7.90 & .101 & 1.30 & .484 & .728 & -7.00 & .000 & 14.40 & .252 & .344 & 0.20 & .93 & -9.40 & .294 & .827 \\
\hline Schaumburg & -22.20 & .000 & 55.00 & .013 & .054 & -1.40 & .206 & 100.50 & .000 & .002 & -17.90 & .000 & 64.50 & .006 & .005 \\
\hline Shreveport & 0.30 & .933 & -22.90 & .065 & .203 & 0.80 & .559 & -37.50 & .003 & .049 & -0.50 & .872 & -13.40 & .198 & .314 \\
\hline St. Louis & -19.90 & .008 & -6.30 & .345 & .755 & -14.70 & .000 & 42.00 & .036 & .101 & -5.50 & .185 & -3.40 & .407 & .769 \\
\hline Vancouver & -1.20 & .547 & 9.90 & .319 & .827 & 3.50 & .000 & 14.20 & .249 & .837 & -5.60 & .011 & -11.70 & .232 & .39 \\
\hline Wayne County & -22.80 & .000 & 14.70 & $.24 I$ & .634 & -12.70 & .000 & 83.50 & .001 & .031 & -7.80 & .002 & -8.80 & .291 & .828 \\
\hline
\end{tabular}

Note. For the three performance metrics (RevPAR, ADR, and OCC), "\% change" is the percentage change in the index metric (value of the index after the event minus the value of the index before, divided by the value of the index before); " $t$ test $p$ value" is the $p$ value of the $t$ test for the difference in values before and after the event; "\% change in SD" is the percentage change in the standard deviation of the metric (standard deviation after the event minus standard deviation before, divided by the standard deviation before); " $F$ test $p$ value" is the $p$ value of the $F$ test for the difference in variance (before and after the event); "Levene $p$ value" is the $p$ value of the Levene's test for the difference in variance (before and after the event). The values in bold indicate statistical significance at the $10 \%$ level or better. RevPAR = revenue per available room; ADR = average daily rate; $O C C=$ occupancy.

Inclusion of the market-specific intercept, or market fixed effect, controls for unobservable characteristics of a given market. Seasonality is allowed to vary across markets, by allowing market-specific monthly dummy variables as indicated by the subscript $i$. The error term (and its variance) is also specific to market $i$. The coefficients that are common across the events are our main coefficients of interest - the coefficient $\beta$ on the post-event dummy variable and the coefficient $\mu$ on the time dummy. In this model, the variance of the residuals $\sigma_{\varepsilon}^{2}$ is also specific to the competitive set for market $i$.

In Model 2, we control for autocorrelation in the time series by adding lagged value of the dependent variable. Model 2 is as follows:

$$
\begin{aligned}
& \text { Performance }_{i, t}=\alpha_{i}+\gamma \text { Performance }_{i, t-1}+ \\
& \beta \text { PostEventDummy }_{i, t}+\mu \text { LongTerm Dummy }_{i, t} \\
& +\sum_{k=1}^{11} \lambda_{k, i} \text { MonthDummy }_{k, i, t}+ \\
& \varepsilon_{i, t}, \operatorname{Var}\left(\varepsilon_{i}\right)=\sigma_{i}^{2} .
\end{aligned}
$$

Like Model 1, Model 2 includes market-specific intercept and monthly dummy variables but now brings in a coefficient on the lagged dependent variable $\gamma$. The coefficient $\beta$ on the post-event dummy, the coefficient $\mu$ on the time dummy, and the coefficient $\gamma$-our main coefficients of interest - are common across the events. In this model, the variance of the residuals $\sigma_{\varepsilon}^{2}$ is specific to the competitive set for hotel $i$ in keeping with a desire to allow for a flexible specification.

In addition to estimating Model 1 and Model 2 with constant variance pre- and post-event, we go one step further and recognize the possibility of a change in the error variance after the event and estimate each of the two models above in two different specifications. The first specification is the single (constant) error variance specification. In this specification, the error variance for each hotel competitive set, $\operatorname{Var}\left[\varepsilon_{i}\right]=\sigma_{i}^{2}$, is the same before and after the event (but is allowed to be different across different competitive sets, as indicated by the subscript $i$ ). In the two- $\sigma_{\varepsilon}$ specification, we allow the variance of the error for each hotel competitive set to be different before and after the event, $\sigma_{i, B e f o r e}^{2}$ and $\sigma_{i, \text { After }}^{2}$. We conduct and report statistical tests for comparison of the two specifications. We also obtain estimates of the error variance before and after the event and observe whether they increase. 
The models are estimated by Maximum Likelihood method, and standard errors are obtained from Fisher Information Matrix (inverse of the negative of the Hessian for the likelihood function, evaluated at the maximum). ${ }^{16}$ The estimates are reported in Table 6.

Table 6, Panel A gives the results for Model 1, for the single error-variance and for the two-error-variance specification. The pooled model is designed to use information contained in all the events and to estimate the impact of the opening of a POH on the competitive set. The coefficient on the postevent dummy variable $\beta$ is negative and strongly statistically significant for all three measures of performance, RevPAR, ADR, and Occupancy. The coefficient on the long-term dummy variable is positive and is statistically significant in five out of six cases; the long-term dummy for ADR in the constant $\sigma_{\varepsilon}$ model is not significantly different from zero. ${ }^{17}$ For all metrics, the post-event dummy is much more strongly significant than the long-term dummy. In all cases, the twoerror-variance specification results in a statistically significant improvement in the likelihood ratio, indicating a better fit. Finally, the use of the two-error-variance specification clearly indicates that the variance post-event is higher than the variance pre-event for all three performance measures.

Table 6, Panel B reports the results for Model 2 (which includes lagged dependent variable to control for potential autocorrelation in the data). The results are reported for both the single error-variance and the two- $\sigma_{\varepsilon}$ specifications. The results are consistent with those obtained in Panel A. The coefficient on the post-dummy variable is negative and strongly statistically significant for all three measures of performance, RevPAR, ADR, and Occupancy. The coefficient on the long-term dummy variable is positive and is statistically significant in only three of the six cases; it shows weak significance for RevPAR, no significance for $\mathrm{ADR}$, and strong statistical significance for OCC. In all cases, the two-error-variance specification results in a statistically better fit and clearly indicates that the variance post-event is higher than the variance pre-event for all three performance measures.

The lag coefficient $(\gamma)$ is strongly significant for all three metrics in both model specifications, indicating strong autocorrelation. The values of the lag coefficients are interesting as well, and appear to be very consistently estimated across the two error specifications; RevPAR and Occupancy have a $50 \%-60 \%$ lag coefficient, while ADR has a lag coefficient of approximately $80 \%$, indicating more inertia in ADR than in RevPAR and OCC. Finally, the likelihood ratios for the Model 2 (Panel B) specifications dominate the likelihood ratios for the Model 1 (Panel A) specifications. We interpret the combination of the strong fit on the lag coefficient and the likelihood ratio dominance as indicating that the Model 2 specification is superior to the Model 1 specification. ${ }^{18}$
The results are consistent in all estimated pooled models: The impact of opening a $\mathrm{POH}$ is negative and strongly statistically significant for all three performance metrics used, and the competitive set indexes do not fully recover over time. Table 7 summarizes the economic impact of the POHs on the competitive set indices. The top panel shows impacts based on the Model 2 specification results, whereas the bottom panel shows impacts based on the Model 1 specification results.

To begin, examine the left side of Panel B that shows the two-error-variance Model 1 specification. Table 6 shows the post-event dummy ( $\beta$ ) for RevPAR equals -0.06848 , with $t$ statistic of -10.41 . Recovery in the index is estimated by a significantly positive coefficient on the long-term dummy $\mu$; for RevPAR, we obtain an estimate of $0.0155636(t=2.09)$. We interpret these results to indicate that the initial drop in RevPAR is $6.848 \%$ but that RevPAR recovers to a drop of $5.292 \%$ in the fourth year (calculated as $\beta+\mu=-0.06848+$ $0.0155636=-0.05292$ ) using the two- $\sigma_{\varepsilon}$ specification. All Panel B results are calculated in a similar fashion.

Panel A is calculated as follows. The long-term impact is estimated as $(\beta+\mu) /(1-\gamma)$, while the initial impact is estimated as $\beta /(1-\gamma) .{ }^{19}$ Examine the left side of Panel A which shows the two-error-variance Model 2 specification. Table 6 shows that the estimated RevPAR coefficient equals -0.03317 , with $t$ statistic of -6.81 . Recovery in the index is estimated by a non-significant coefficient on the long-term dummy $\mu$; for RevPAR, we obtain an estimate of 0.006847 $(t=1.11)$. We interpret these results to indicate that the initial drop in RevPAR is $7.588 \%$ but that RevPAR recovers to a drop of $5.998 \%$ in the fourth year, calculated as -0.03317 $/(1-0.561108)=-0.07588$ and $(-0.03317+0.006847) /$ $(1-0.561108)=-0.05998$. All Panel A results are calculated in a similar fashion.

With these preliminaries complete, we examine the Table 7 results. The first thing to notice is that the long-term impact on RevPAR is very consistently estimated in the range of a drop of $5.29 \%$ to $6.23 \%$, after initial drop of $6.85 \%$ to $8.35 \%$. The Panel A results are even more tightly estimated with a drop of approximately $6 \%$ after initial drop of approximately $7.5 \%$ to $8 \%$. In the Model 2 (Panel A) specification, there is strong evidence of a long-term drop of approximately $3.5 \%$ in ADR with no recovery. The Model 1 (Panel B) specification shows long-term drop of between $1.5 \%$ and $2 \%$ after initial drop of $2.2 \%$ to $2.4 \%$.

The long-term impact for occupancy shows mixed results. The Model 2 (Panel A) specification indicates a long-term drop of approximately $1.6 \%$ after initial drop of approximately 3.7\%. The Model 1 (Panel B) specification indicates a long-term drop of approximately $2.5 \%$ after initial drop of approximately $3.5 \%$. There is strong evidence to indicate a statistically significant recovery in OCC in the long term. Interestingly, the long-term impact on RevPAR is greater than what one finds by multiplying the ADR and 


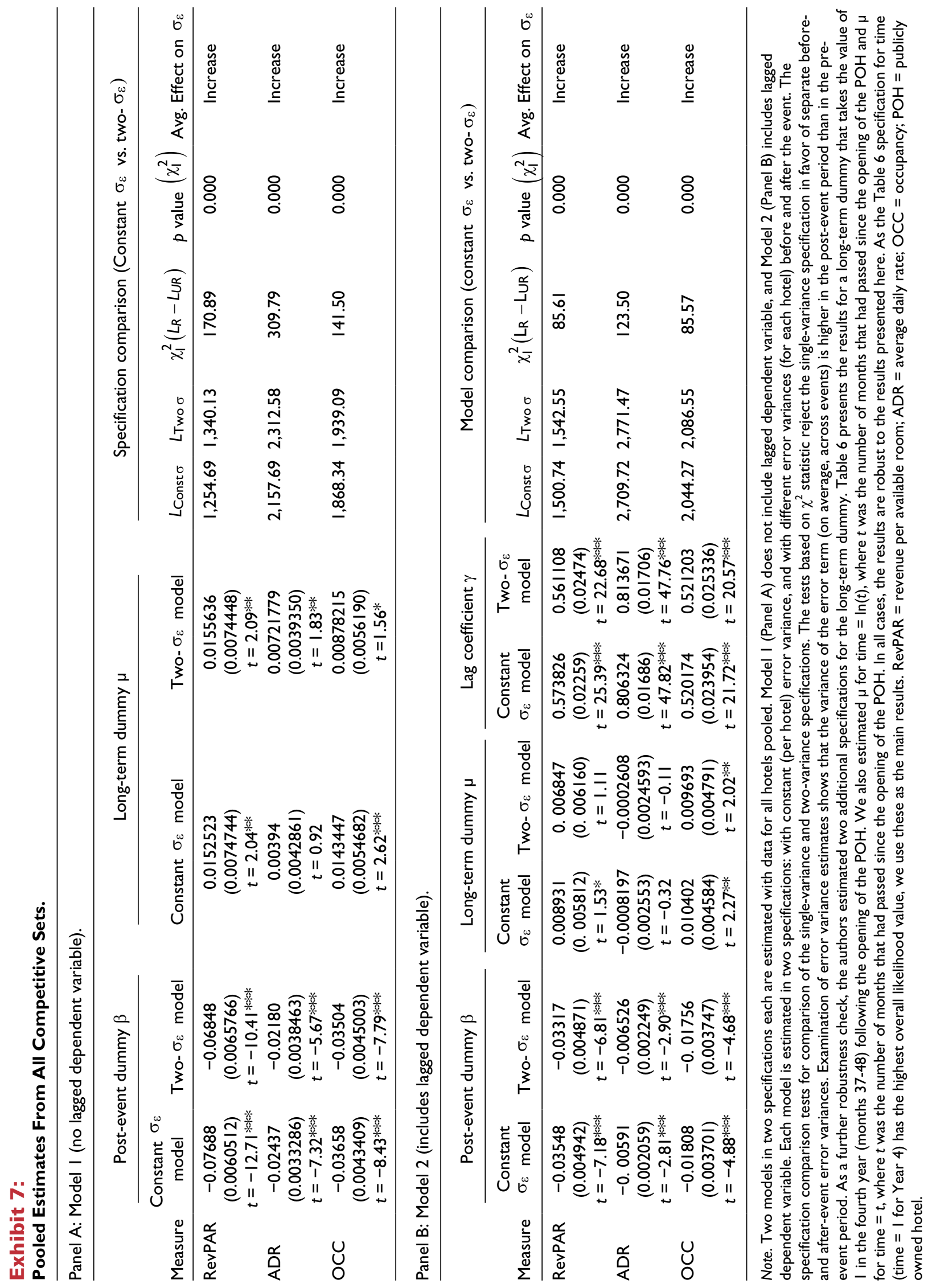




\section{Exhibit 8:}

Pooled Results: Impact of Publicly Owned Hotels on the Competitive Set Indexes.

Panel A: Lagged dependent variable (Model 2) specification.

\begin{tabular}{lcccc}
\hline & \multicolumn{2}{c}{ Two- $\sigma_{\varepsilon}$ model } & \multicolumn{2}{c}{ Constant $\sigma_{\varepsilon}$ model } \\
\cline { 2 - 5 } & Initial impact & Long-term impact & Initial impact & Long-term impact \\
\hline RevPAR & $-7.558 \%$ & $-5.998 \%$ & $-8.325 \%$ & $-6.230 \%$ \\
ADR & $-3.502 \%$ & $-3.642 \%$ & $-3.053 \%$ & $-3.476 \%$ \\
OCC & $-3.666 \%$ & $-1.641 \%$ & $-3.768 \%$ & $-1.600 \%$ \\
\hline
\end{tabular}

Panel B: No lagged dependent variable (Model I) specification.

\begin{tabular}{lcccc}
\hline & \multicolumn{2}{c}{ Two- $\sigma_{\varepsilon}$ model } & \multicolumn{2}{c}{ Constant $\sigma_{\varepsilon}$ model } \\
\cline { 2 - 5 } & Initial impact & Long-term impact & Initial impact & Long-term impact \\
\hline RevPAR & $-6.848 \%$ & $-5.292 \%$ & $-7.688 \%$ & $-6.163 \%$ \\
ADR & $-2.180 \%$ & $-1.458 \%$ & $-2.437 \%$ & $-2.043 \%$ \\
OCC & $-3.504 \%$ & $-2.626 \%$ & $-3.658 \%$ & $-2.224 \%$ \\
\hline
\end{tabular}

Note. The coefficient estimates from the two pooled model specifications from Table 5 are used to estimate the economic impact of POHs on the index for the competitive sets. Panel A presents the most flexible specification, which recognizes the significant autocorrelation in the data. Panel $B$ is presented as a robustness check. RevPAR $=$ revenue per available room; $A D R=$ average daily rate; $O C C=$ occupancy; $P O H=$ publicly owned hotel.

\section{Exhibit 9:}

Maximum Likelihood Results Summary: Number of Changes in the Individual Competitive Sets.

\begin{tabular}{|c|c|c|c|c|c|c|}
\hline & \multicolumn{6}{|c|}{ Change in market performance } \\
\hline & \multicolumn{2}{|c|}{ Improved performance } & \multicolumn{2}{|c|}{ Worse performance } & \multicolumn{2}{|c|}{ Not statistically significant } \\
\hline & $\begin{array}{l}\text { Post-event } \\
\text { dummy }(\beta)\end{array}$ & $\begin{array}{l}\text { Long-term } \\
\text { dummy }(\beta)\end{array}$ & $\begin{array}{l}\text { Post-event } \\
\text { dummy }(\beta)\end{array}$ & $\begin{array}{l}\text { Long-term } \\
\text { dummy }(\beta)\end{array}$ & $\begin{array}{l}\text { Post-event } \\
\text { dummy }(\beta)\end{array}$ & $\begin{array}{l}\text { Long-term } \\
\text { dummy }(\beta)\end{array}$ \\
\hline RevPAR & 4 & 8 & 17 & 13 & 0 & 0 \\
\hline ADR & 8 & 8 & 13 & 13 & 0 & 0 \\
\hline OCC & 7 & 12 & 14 & 9 & 0 & 0 \\
\hline
\end{tabular}

Note. The table shows the count of statically significant market changes out of the 21 markets with POH introductions using Model 2 to estimate a unique post-event dummy $(\beta)$ and a unique long-term dummy $(\mu)$ for each hotel. RevPAR = revenue per available room; ADR = average daily rate; $\mathrm{OCC}=$ occupancy; $\mathrm{POH}=$ publicly owned hotel.

OCC results, indicating that the RevPAR drop is more profound than simply the changes in ADR and OCC.

We interpret these results as indicating strong evidence that the introduction of a $\mathrm{POH}$ has a negative impact on hotels in the POH's competitive set, even after adjusting for a recovery. Interestingly, the impact on occupancy and ADR is not as expected. It appears as if there is some support for the notion that the demand for hotel accommodation recovers in markets with the introduction of the $\mathrm{POH}$. Surprisingly, the drop in ADR never recovers after the introduction of the $\mathrm{POH}$, contributing to the overall drop in RevPAR.

\section{Results From the Individual Hotel Maximum Likelihood Models}

Next, we estimate Model 2 (two-error-variance specification) for each of the 21 markets to obtain a unique post-event dummy $(\beta)$ and unique long-term dummy $(\mu)$ coefficient estimates for each hotel; this specification allows for seasonality via monthly dummies as well as a unique lag coefficient for each market. ${ }^{20}$

Table 8 reveals that the results are much more statistically significant than the univariate results in Table 4, with none of the markets showing a lack of statistical significance for the post-event dummy $(\beta)$ and the long-term dummy $(\mu)$. Like the univariate results, the individual market results point to a significant deterioration in performance for RevPAR and for ADR. Interestingly, a majority of the competitive sets (12 of 21) show a statistically significant long-term increase in OCC, while a majority of the competitive sets show a statistically significant long-term decrease in RevPAR and OCC (13 of 21 for both metrics). Table 9 presents the Post-Event Dummy $(\beta)$ and a Long-Term Dummy $(\mu)$ and their level of significance for each of the competitive set indexes. Note 
that the estimates vary over a great range, both for the postevent dummy and for the long-term dummy. We provide a graphical view in Figures 2 and 3.

Of the three metrics of RevPAR, ADR, and OCC, it is the first that provides the most complete picture of market strength as it incorporates both ADR and OCC. We have plotted the initial change and the long-term change to the competitive set index for RevPAR for the 21 individual competitive sets in Figure 2, using the data from Table 9.

The 21 competitive sets are organized horizontally by city name. An outcome in support of the positive externalities hypothesis has outcomes above the $0 \%$ line, that is, higher RevPAR index. An outcome in support of the $\mathrm{POH}$ damages hypothesis has outcomes below the $0 \%$ line, that is, lower RevPAR index. For each market, there are two bars. The initial change as estimated by the post-event dummy is represented by the left bar and long-term impact (post-event dummy \pm the long-term dummy) is to the right. The purpose is to see how the metrics change, both initially and after allowing 4 years for market recovery.

One might expect to see evidence that over time markets would recover in a way that benefits competing hotels in the long run. Although there are some examples of this including Austin, Coralville, Denver, Midwest City, Providence, and Vancouver, this is not a predominant trend. Figure 2 clearly shows that negative scenarios predominate both in the number of cases and in the severity of the impact. This is true in both the short and long-term perspectives. These trends do not support claims that $\mathrm{POH}$ produce positive externalities that benefit existing hotels in the market. The dominant scenario, both in terms of the number of cases and the severity of the impacts, is that competing hotels were hurt by the entry of POHs into their markets. Furthermore, the data do not show consistent patterns of market recovery over time.

Figure 3 takes RevPAR index as a measure of market strength and plots it against market volatility to create a four-quadrant model illustrating the impact of the openings of $\mathrm{POH}$ in each of our 21 markets. The vertical axis plots the long-term change in the competitive set RevPAR index while the horizontal axis plots the change in the competitive set RevPAR index standard deviation.

This gives us four quadrants that we have labeled accordingly:

- The upper right quadrant is where the competitive set index got stronger and less volatile after the introduction of a POH, and is labeled Game Changers.

- The upper left quadrant is where the competitive set index got stronger, but more volatile after the introduction of a $\mathrm{POH}$, and is labeled Swinging for the Fences.
- The lower right quadrant is where the competitive set index got weaker, but less volatile after the introduction of a $\mathrm{POH}$, and is labeled Strikeout Looking.

- The lower left quadrant is where the competitive set index got both weaker and more volatile after the introduction of a $\mathrm{POH}$, and is labeled Strikeout Swinging.

If the null hypotheses are false and POHs produce positive externalities for the competitive hotels, we would expect to find observations in the upper two quadrants, with the upper right dominating the upper left as one would prefer less volatility to more volatility. If the null hypothesis is false and POHs dilute the market for the competing hotels, we would expect to find observations in the lower two quadrants, with the lower left being worse than the lower right due to the increase in volatility.

Our analysis shows that the positive externality scenario is very elusive for hotels in the competitive set. Only seven of the 21 markets show an increase in the competitive RevPAR index, even after allowing for a recovery over time. For a POH to be a "game changer," it would need to show a statistically significant increase in RevPAR and a statistically significant decrease in its standard deviation. In fact, we did not find any statistically significant "game changers" in the entire population of U.S. hotels that are wholly publicly owned, where there is sufficient data from their competitive sets to conduct our analyzes. The Austin market shows up in the RevPAR "game changer" quadrant; while the change in the competitive set RevPAR index was significant, the reduction in standard deviation was not. For the remaining six markets that showed modest increases in their RevPAR indices in Figure 3, with five being statistically significant, this came at the expense of more volatility, and thus these markets fall into the "swinging for the fences" quadrant.

Fifteen of the 21 markets exhibit a decline in the competitive set RevPAR index. Five markets fall into the "strikeout looking" category where RevPAR indices fell, but the markets were slightly less volatile. Of these five, only the Sheraton Overland Park competitive set experienced a statistically significant decrease in volatility. Within this category, statistically significant decreases in the RevPAR indices were found in Baltimore, Lombard, Overland Park, and St. Louis. Nine markets fall into the least desirable "strikeout swinging" category where the RevPAR of existing hotels in the market got both weaker and more volatile. Within this category, seven markets had statistically significant decreases in RevPAR indices while three had statistically significant increases in volatility. The Pittsburgh airport and Schaumburg competitive sets had the 


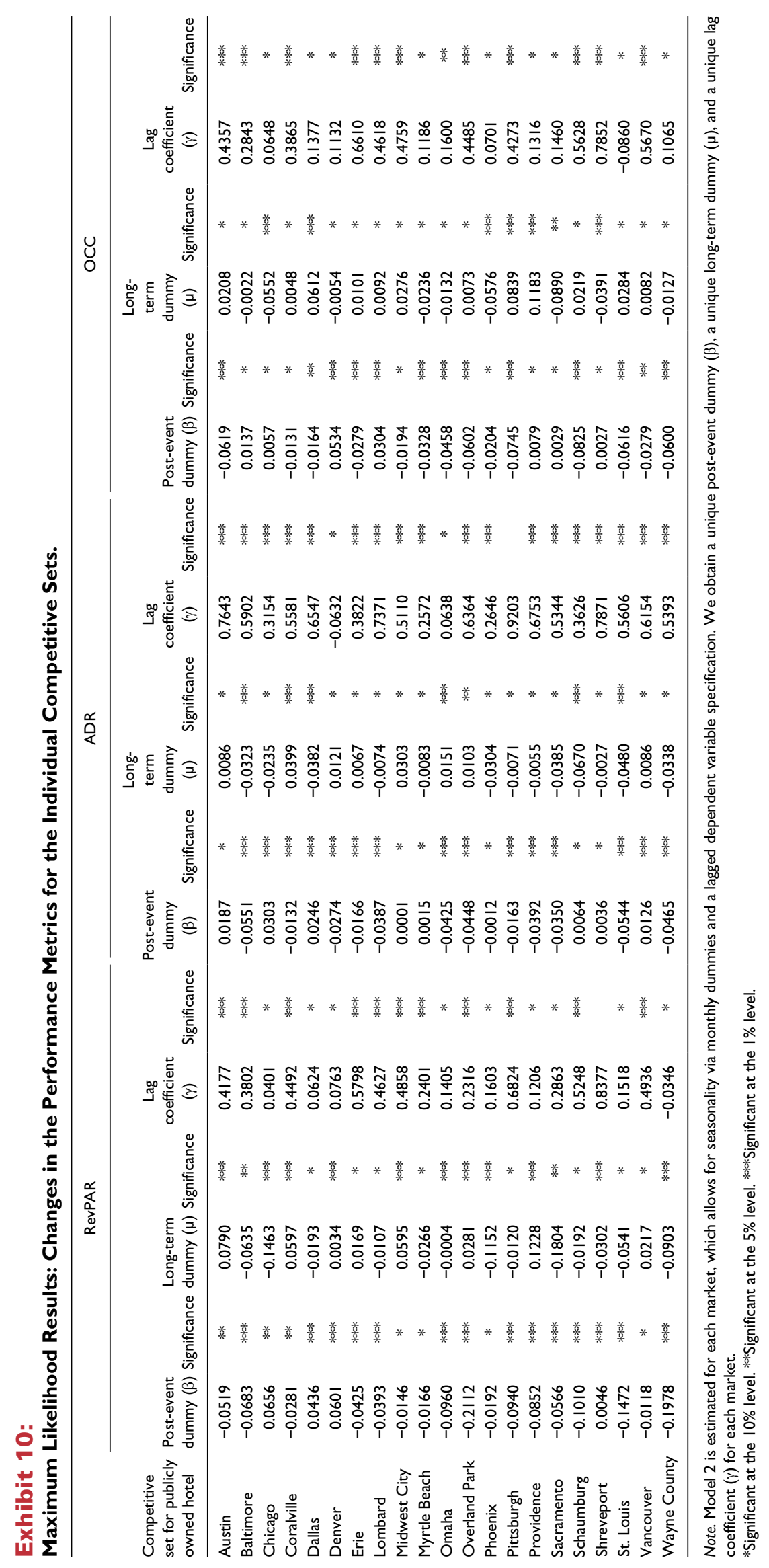




\section{Exhibit 11:}

Impact of POH on RevPAR of individual competitive sets.

\section{Impact on Competitive Set RevPAR Indices After the Opening of a POH}

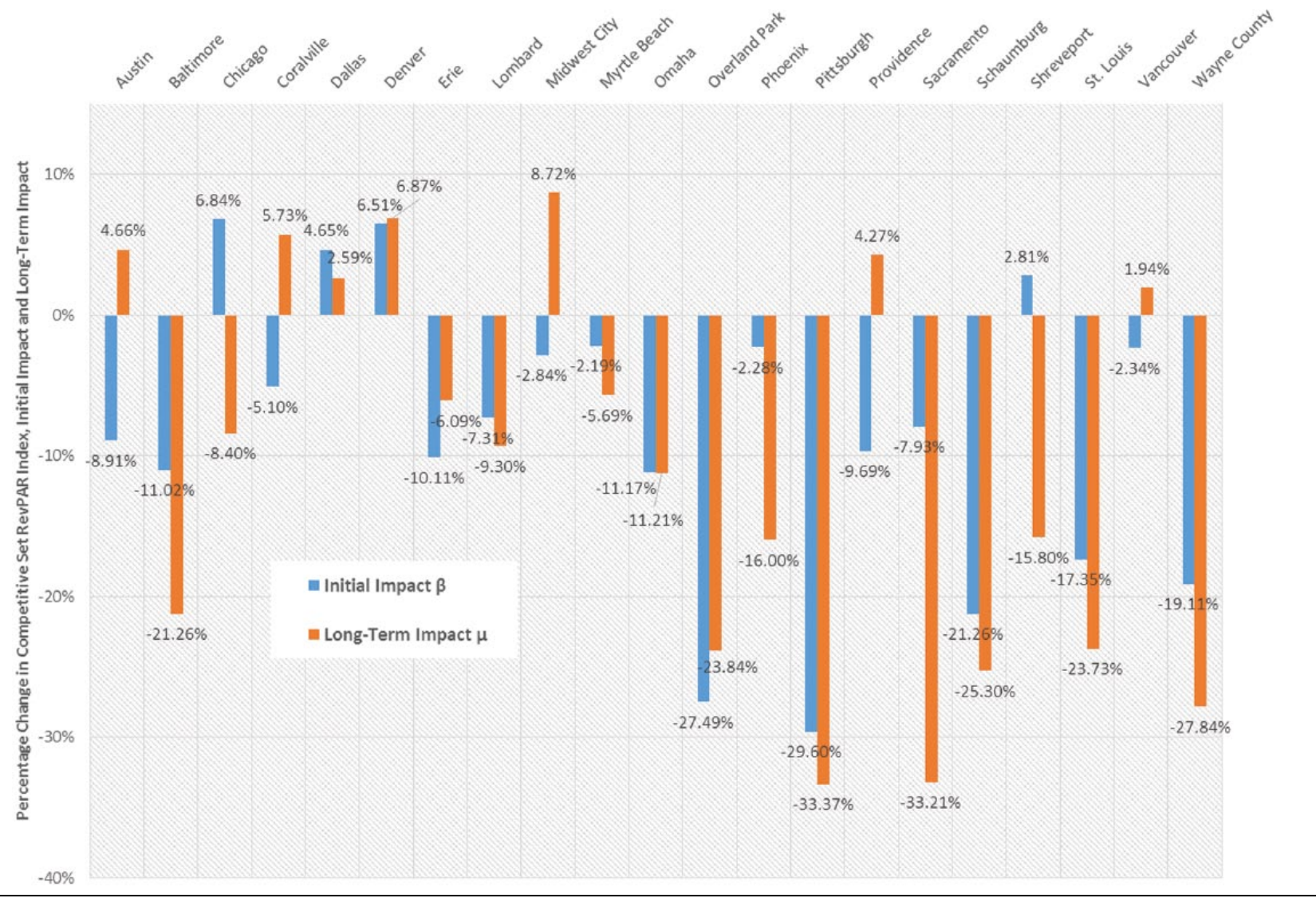

Note. The figure shows the initial impact and the long-term impact of the introduction of a POH on the RevPAR index of the individual competitive sets using the Model I Maximum Likelihood method. POH = publicly owned hotel; RevPAR = revenue per available room.

dubious distinction of having statistically significant negative impacts on both their RevPAR indices and volatility once POHs opened in their markets.

\section{Conclusion}

This study utilizes statistical tests based on several approaches: the whole sample univariate statistics; the individual hotel univariate tests; a set of pooled models that control for seasonality, autocorrelation, and the potential for improved performance over time; and individual competitive set models that control for seasonality and the potential for improved performance over time. The results from all these tests are consistent; there is deterioration in performance metrics for competitive sets following the introduction of a $\mathrm{POH}$.

Given the impact of the universe of POHs in the United States on competing hotels, it is hard to make the case that any $\mathrm{POH}$ generated significant positive externalities to the existing stock of hotels competitive with the $\mathrm{POH}$ by attracting enough new demand to a market where competing hotels benefited from the public good. On the contrary, POHs tend to erode the key performance metrics of competitive hotels in the market. As can be seen in Figure 2, there was a significant improvement in the RevPAR indices of competing hotels in only five of the 21 markets. The pooled models that pull together the composite data of all the markets in our study yield similar results. For all three performance metrics, in all four statistical specifications, the pooled model identifies the negative impact on performance of the competitive set.

In addition to the effect on the level of performance, we also point out that there is an effect on variability. This is an important but often overlooked effect. The data in those markets that saw increases in volatility suggest that the addition of the $\mathrm{POH}$ helped attract enough visitors during peak season to absorb the additional inventory and created spillover business that benefited other hotels, but this was 


\section{Exhibit 12:}

Percentage change in competitive set RevPAR index and volatility after the introduction of a POH.

\section{Percentage Change to RevPAR Index and Volatility of Competitive Sets}

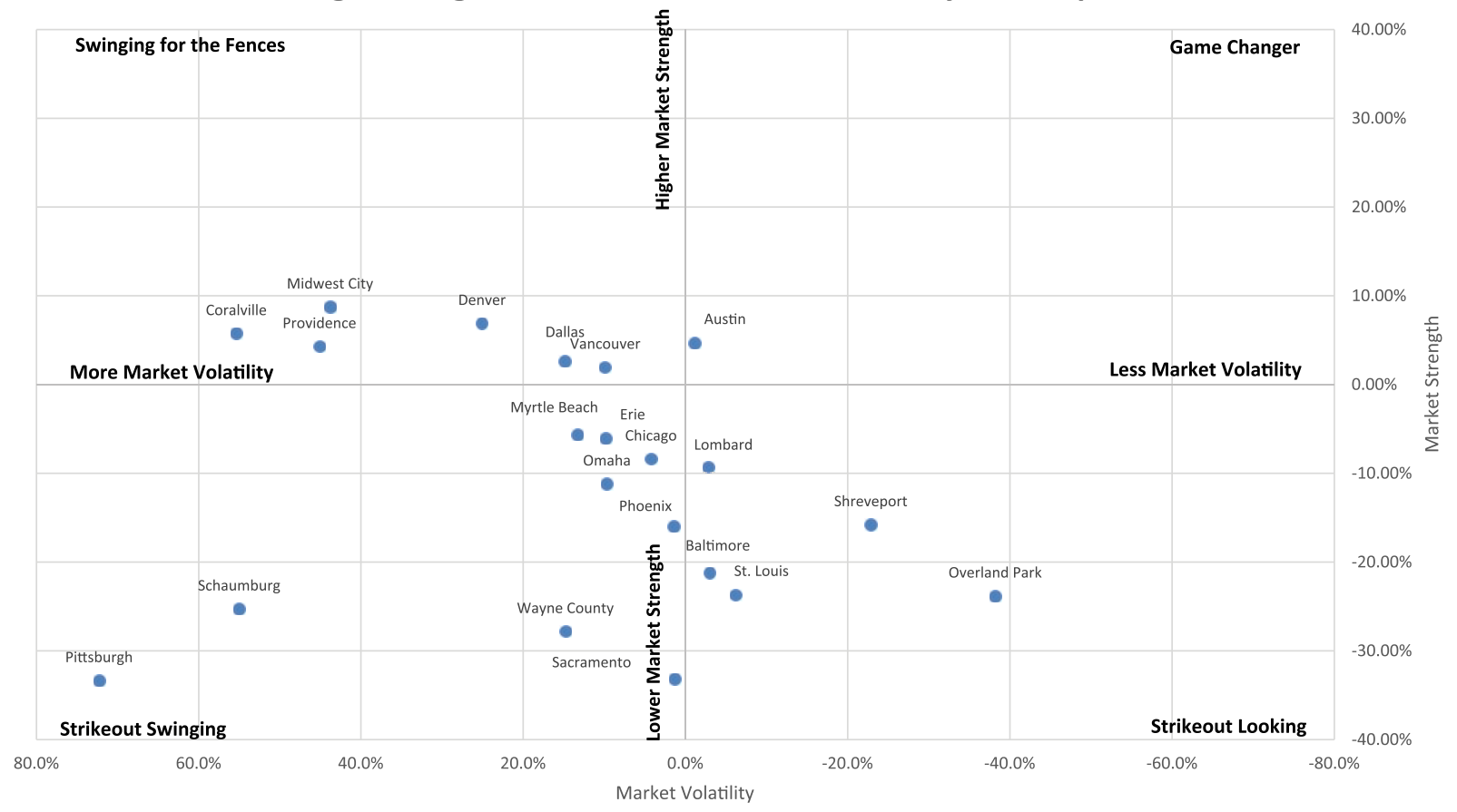

Note. The figure plots the long-term impact on the individual competitive set RevPAR index and the change in the RevPAR index standard deviation. The horizontal axis is the change in the index standard deviation from Table 2, and the vertical axis is the long-term impact from Figure 2. The upper right quadrant is where the market got stronger and less volatile after the introduction of a POH. The upper left quadrant is where the market got stronger, but more volatile after the introduction of a $\mathrm{POH}$. The lower right quadrant is where the market got weaker, but less volatile after the introduction of a POH. The lower left quadrant is where the market got both weaker and more volatile after the introduction of a POH. RevPAR $=$ revenue per available room; $\mathrm{POH}=$ publicly owned hotel.

not the case during the soft season where the added inventory drove down occupancies and rates. Increases in market volatility measured by the percent changes in the standard deviations of market RevPAR indices were found in 15 of 21 cases once the POH entered the market. In five of these cases, the increased market volatility was statistically significant at the $10 \%$ level or better. There is only one case of a statistically significant decrease in RevPAR volatility (the case of Sheraton Overland Park), but it comes at a price of a 27\% decline in RevPAR level ( $p$ value of .000). Volatility increases in other metrics too. In 11 out of 21 markets, there is an increase in the volatility of occupancy (five cases are statistically significant), and there is no market with a statistically significant decline in occupancy index volatility. ADR index becomes substantially more volatile once the $\mathrm{POH}$ enters the market. ADR volatility increases in 17 of the 21 markets (in 10 of the 17 cases, the increase is statistically significant).

The question of how the introduction of a $\mathrm{POH}$ affects investments that private sector investors made in existing hotels has long been an important part of the debate over the use of public money for these projects. Proponents of POHs claim that their project will be a rate leader that will draw enough new business so that competing hotels in the market will benefit from these public goods. Others express fears that $\mathrm{POHs}$ are unfair competition that steal market share from the investments that private sector developers made in existing hotels. To date, these arguments, both pro and con, have been anecdotal with little in the way of reliable data to back either side.

For the first time, this study quantifies the impact that POHs have had on performance metrics of existing competing hotels in each of the 21 U.S. markets where there is adequate data for analysis. The overall picture that emerges from the analysis is one of deteriorating performance and of more volatile markets after the introduction of a $\mathrm{POH}$. There is only a single market that emerges as a convincingly improved case. The data show that POHs tend to harm the performance metrics of existing hotels that most closely compete with them. Not only does performance decline but, in most cases, the markets become more volatile. The effect is observed in all three commonly used measures of performance: RevPAR, ADR, and OCC. The effects are statistically significant and economically meaningful. 
This article provides compelling evidence that the introduction of POHs harms the hotels that are most competitive with the POH; policymakers, governmental officials, and hotel operators should proceed with caution and be aware that the "rising tide hypothesis" is rarely seen in practice.

\section{Acknowledgments}

The authors acknowledge the assistance of the many individuals who helped in creating the databases used in this article: Bruce Baltin at PKF Consulting; Thomas Hazinski at HVS; Steven Hood at STR Global; Raymond Garfield of Encore Garfield Public/Private, LLC; and Gregg Rockett at Hilton Hotels. They thank Crocker Liu and Michael Lynn of Cornell University for helpful discussions.

\section{Declaration of Conflicting Interests}

The author declared no potential conflicts of interest with respect to the research, authorship, and/or publication of this article.

\section{Funding}

The author received no financial support for the research, authorship, and/or publication of this article.

\section{Notes}

1. For details on the many forms that subsidies can take, see Nelson, Baltin, and Feighner (2012).

2. Sanders (2005a) is a good example of the argument against publicly owned hotels (POHs).

3. See Hazinski and Laubacher (2002), for a classic example.

4. See, for example, Morgan and Condliffe (2006) and Fenich (1992) for papers providing support for significant positive externalities argument. Morgan and Condliffe provide labor multipliers for construction, dining, and lodging as a result of increased tourism or convention spending.

5. Rubin (2000, page 4) states,

Hotel development in or near public convention facilities has always been a little problematic . . . if a hotel relies solely on rooms business generated in tandem with the convention center, it is difficult to achieve occupancy of much more than $55 \%$ to $57 \%$ on an annual basis . . . because major meetings and conventions required time to set up and time to tear down ... So the economic viability of convention center hotel development has . . typically been seen as something less than a sure based on typical location factors alone.

6. Blocher (2006, pages 370-371) provides an example:

... A developer may be faced with the prospect of building a hotel at a cost of $\$ 10$ million. She expects to receive $\$ 9$ million in total receipts over the life of the hotel from the hotels customers. Additionally, the hotel is expected to confer $\$ 3$ million of benefits to non-customers, including the value of spillover business from hotel customers, prestige for the town, enjoyment of the building's architecture, and so on. Despite the total gross benefit of $\$ 2$ million ( $\$ 9$ million to the developer plus $\$ 3$ million to third parties, minus the $\$ 10$ million in construction costs), the developer will not build hotel, unless she has a way to collect some of the $\$ 3$ million of public benefits.

7. Rosen and Gayer (2008) say,

Many people ... understand that if they can convince the government their activities create beneficial spillovers, they may be able to dip into the treasury for a subsidy. The quest for such subsidies must be viewed cautiously . . . every subsidy embodies a redistribution of income [and] may not be desirable . . . a subsidy is appropriate only if the market does not allow those performing the activity to capture the full marginal return. (Chapter 8 "Externalities," pp. 101-102)

8. Externalities and effectiveness of subsidies are an area of active research, both theoretical and empirical. Among recent papers are Parry and Small (2009), which develops a theory and empirically tests these in the context of urban transportation subsidies; an empirical study of externalities in the transportation sector by Bento et al. (2014); an empirical study of mortgage subsidies and home ownership by Fetter (2013); a theoretical study of contracting in the presence of heterogeneous externalities by Bernstein and Winter (2012); and a theory of taxation and subsidies in a production economy by Philippon (2010). Morrison and Siegel (1999) develop a model of agglomeration externalities and estimate it for U.S. manufacturing industries, and Harstad (2007) develops a game theoretic model of political cooperation among regions that try to internalize externalities. Despite the active research on externalities and subsidies within different settings, surprisingly little empirical work has been done on subsidies in the hotel sector.

9. Chapter 2, "Urban Tourism and the Privatizing Discourses of Public Infrastructure" by D. C. Perry, applies Rosen and Gayer's (2008) cautionary note regarding public subsidy to convention center development, and Chapter 3, "Tourism and Entertainment as Local Economic Development: A National Survey" by D. R. Judd et al., provides numerous examples of public-private partnerships.

10. In the introduction, the authors state,

The private sector's involvement in tourism is profit driven. When the risks are seen as too great, private investors or public sector leaders frequently initiate efforts to form partnerships between private investors, governments, foundations, and even pension fund organizations to pay for part of all of the costs of building an amenity. The investments by the public or nonprofit partners reduce the risks to the private sector partner and help to insure profitability of the project and market-rate returns to private capital. (Rosentraub \& Joo, 2009, p. 764)

11. The Trenton Marriott at Lafayette Yard lost its franchise, went bankrupt, and was sold in 2013.

12. As a technical matter, STR Global requires that a competitive set of hotels consist of four or more properties to make it impossible to determine the metrics of any one hotel. We used STR Analytics "Comp Set Suite" product to verify the competitive sets. Many thanks to Carter Wilson and Duane Vinson at STR Analytics for their assistance. 
13. Enz, Kosová, and Lomanno (2011) use a similar approach to examine the impact of the $9 / 11$ terrorist attacks and the 2008 economic shock on the above mentioned hotel metrics for the entire U.S. market.

14. Levene's (1960) test is an inferential statistic used to assess the equality of variance for a variable calculated for two or more groups. It tests the null hypothesis that the variances are equal. It may be used as a test for answering the question of whether two sub-samples in a given population have equal or different variances. Levene's test is less sensitive to departures from normality than most tests.

15. The maximum likelihood approach to model estimation (MLE) gives several advantages over ordinary least squares (OLS) regression when applied to our research question. MLE gives us the flexibility to estimate pooled models with fine control over which coefficients are identified by the entire data set versus which coefficients are event specific. For example, we estimate models that allow autocorrelation to be different in different markets, and we also estimate models where autocorrelation is treated as a pooled estimate. Another important advantage of the MLE approach is the flexible error structure. Although OLS applied to an event study would assume that the variance of the error term is fixed (the same before and the same after the event), MLE is free from this restriction and allows us to estimate models with different error variances before and after the event. Empirically, we find this feature is important.

16. All estimations for the pooled models were performed using the numerical maximization functions in Mathematica ${ }^{\circledR}$ version 10 .

17. As a robustness check, the authors estimated all the models above with two additional specifications for the long-term dummy. Table 6 presents the results for a long-term dummy that takes the value of 1 in the fourth year (months 37-48) following the opening of the $\mathrm{POH}$. We also estimated $\mu$ for time $=\ln (t)$, where $t$ was the number of months that had passed since the opening of the $\mathrm{POH}$ and estimated $\mu$ for time $=t$, where $t$ was the number of months that had passed since the opening of the $\mathrm{POH}$. In all cases, the results are robust to the results presented here. As the Table 6 specification for time (time $=1$ for Year 4 ) has the highest overall likelihood value, we use these as the main results.

18. As a further robustness check, we allowed for the most flexible model which includes hotel-specific lagged dependent variables and hotel-specific error variance that may be different before and after the event. In this model, we estimate 274 coefficients in addition to 42 variances of the error term. The model allows for event-specific and market-specific characteristics, yet it is able to obtain remarkably precise estimates of the main coefficient of interest. For all three measures of performance, the estimate of $\beta$ is negative and strongly statistically significant, while the estimates of $\mu$ are weakly significant. These results are consistent with the results reported in Table 6.

19. These expressions take into account the estimated autoregressive component.

20. Here, we use the same long-term dummy specification as in Table 6, which presents the results for a long-term dummy that takes the value of 1 in the fourth year following the opening of the POH. We also estimated $\mu$ for time $=\ln (t)$ and $\mu$ for time $=t$. In all cases, the results are robust to the results presented in Tables 8 and 9. As the specification for time $=$ 1 for Year 4 has the highest overall likelihood value, we use these as the presented results. As a further robustness check, we estimated Model 1 (no lagged dependent variable) for each of the 21 markets; the results are remarkably robust to the Model 2 estimates, although with lower likelihood values.

\section{References}

Bartik, T. J. (1990). The market failure approach to regional economic development policy. Economic Development Quarterly, 4, 361-370.

Bartik, T. J. (2005). Solving the problems of economic development incentives. Growth and Change, 36, 136-166.

Bento, A., Kaffine, D., Roth, K., and Zaragoza-Watkins, M. (2014). The effects of regulation in the presence of multiple unpriced externalities: Evidence from the transportation sector. American Economic Journal: Economic Policy, 6(3), 1-29.

Bernini, C., and Pellegrini, G. (2011). How are growth and productivity in private firms affected by public subsidy? Evidence from a regional policy. Regional Science and Urban Economics, 41, 253-265.

Bernini, C., and Pellegrini, G. (2013). Is subsidising tourism firms an effective use of public funds? Tourism Management, 35, 156-167.

Bernstein, S., and Winter, E. (2012). Contracting with heterogeneous externalities. American Economic Journal: Microeconomics, 4, 50-76.

Blocher, J. (2006). Private business as public good: Hotel development and Kelo. Yale Law \& Policy Review, 24, 363-397.

Boo, S., and Kim, M. (2010). The influence of convention center performance on hotel room nights. Journal of Travel Research, 49, 297-309.

Choy, D. J. L. (1991). Tourism planning: The case for "market failure." Tourism Management, 12, 313-330.

Clark, J. D. (2007). What are cities really committing to when they build a convention center? In R. R. Nelson (Ed.), Developing a successful infrastructure for convention \& event tourism (pp. 7-27). Binghamton, NY: Haworth Hospitality Press.

Detlefsen, H. (2012). Public-private partnerships: A strategy to minimize public subsidies. New York, NY: HVS. Retrieved from http://www.hvs.com/article/5620/public-private-partnerships-a-strategy-to-minimize-public

Dwyer, L., Forsyth, P., and Spurr, R. (2004). Evaluating tourism's economic effects: New and old approaches. Tourism Management, 25, 307-317.

Edwards vs. Erie County. Retrieved from http://www.leagle.com/ xmlResult.aspx? $x$ mldoc $=20071929932$ A2d997_11896.xml

Enz, C., Kosová, R., and Lomanno, M. (2011). The impact of terrorism and economic shocks on U.S. hotels. Cornell Hospitality Report, 11(5), 1-17.

Fenich, G. G. (1992). Convention center development: Pros, cons and unanswered questions. International Journal of Hospitality Management, 11, 183-196.

Fetter, D. (2013). How do mortgage subsidies affect home ownership? Evidence from the mid-century GI bills. American Economic Journal: Economic Policy, 5, 111-147.

Gee, K. G., and Singh, A. J. (2008). International hotels: Development and management (2nd ed.). Washington, DC: American Hotel \& Lodging Educational Institute. 
Harberger, A. C. (1974). Taxation and welfare. Chicago, IL: University of Chicago Press.

Harstad, B. (2007). Harmonization and side payments in political cooperation. American Economic Review, 97, 871-889.

Hazinski, T. (2004). Public involvement in hotel financing. Chicago, IL: HVS. Retrieved from http://www.hvs.com/article/1325/public-involvement-in-hotel-financing

Hazinski, T. (2010). How convention centers influence hotel markets. Chicago, IL: HVS. Retrieved from http:/www.hvs.com/ article/4405/how-convention-centers-influence-hotel-markets

Hazinski, T., and Laubacher, M. (2002). Tax-exempt hotel financing: A primer for finance officers. Government Finance Review, 18, 32-35.

Judd, D. R. (2003). The infrastructure of play: Building the tourist city. Armonk, NY: M. D. Sharpe.

Laslo, D. H., and Judd, D. R. (2005). Convention center wars and the decline of local democracy. Journal of Convention \& Event Tourism, 6, 81-98.

Levene, H. (1960). Robust tests for equality of variances. In I. Olkin (Eds.), Contributions to probability and statistics: Essays in honor of Harold Hotelling (pp. 278-292). Stanford, CA: Stanford University Press.

Milford, M., and Montgomery, J. (2011, October 9). Hotel venture sparks debate. The News Journal, Wilmington, DE.

Mirabella, L. (2005, April 12). Proponents make case for publiclyfinanced Hilton in Baltimore. The Baltimore Sun. Retrieved from http://www.highbeam.com/doc/1G1-131349752.html

Morgan, A., and Condliffe, S. (2006). Measuring the economic impacts of convention centers and event tourism. Journal of Convention \& Event Tourism, 8, 81-100.

Morrison, C. J., and D. S. Siegel (1999). Scale economies and industry agglomeration externalities: A dynamic cost function approach. American Economic Review, 89, 272-290.

Murphy, V. (2005, February 28). The answer is always yes. Forbes. Available from www.Forbes.com

Nelson, R. R. (2006). Public financing of headquarter hotels in the United States. Journal of Convention \& Event Tourism, 8(4), 29-46.

Nelson, R. R., Baltin, B., and Feighner, B. (2012). Public-private financing structures used in the United States to develop convention hotels. Journal of Convention \& Event Tourism, 13, 135-146.

O'Neill, J. W. (2011). Hotel occupancy: Is the three-year stabilization assumption justified? Cornell Hospitality Quarterly, 52, 176-180.

Parry, I. W. H., and Small, K. A. (2009). Should urban transit subsidies be reduced? American Economic Review, 99, 700-724.

Philippon, T. (2010). Financiers versus engineers: Should the financial sector be taxed or subsidized? American Economic Journal: Macroeconomics, 2, 158-182.

Pigou, A. C. (1932). Economics of welfare (4th ed.). London, England: Macmillan.

Rosen, H. S., and Gayer, T. (2008). Public finance (8th ed.). New York, NY: McGraw-Hill.

Rosentraub, M. S., and Joo, M. (2009). Tourism and economic development: Which investments produce gains for regions? Tourism Management, 30, 759-770.

Rubin, K. E. (2000). What can make new hotel construction economically feasible when new hotel construction isn't economically feasible? Real Estate Issues, 25(1), 1-6.
Sanders, H. T. (1999). Flawed forecasts: A critical look at convention center feasibility studies. Boston, MA: Pioneer Institute for Public Policy Research.

Sanders, H. T. (2004a). Convention mythology. In R. R. Nelson (Ed.), Current issues in convention and exhibition facility development (pp. 99-143). Binghamton, NY: The Haworth Hospitality Press.

Sanders, H. T. (2004b, June). Risk and reality in public headquarter hotel development. Government Finance Review, 20, 20-24.

Sanders, H. T. (2005a). Premises and performance of headquarters hotels. Economic Development Journal, 4, 33-43.

Sanders, H. T. (2005b). Space available: The realities of convention centers as economic development strategy. Washington, DC: The Brookings Institute.

Sanders, H. T. (2014). Convention center follies. Philadelphia: University of Pennsylvania Press.

Schwester, R. W. (2007). An examination of the public good externalities of professional athletic venues: Justifications for public financing? Public Budgeting \& Finance, 27, 89-109.

Stiglitz, J. E. (1988). Economics of the public sector (2nd ed.). New York, NY: W.W. Norton.

STR Analytics. (2012). 2012 U.S. lodging tax study. Washington, DC: American Hotel \& Lodging Education Foundation.

Tsukahara, K. (1995). Independent and joint provision of optional public services. Regional Science and Urban Economics, 25, 411-425.

Vonmhof, J. (2013, April 24). Minneapolis convention hotel would cost $\$ 300 \mathrm{M}$, require subsidies: Study. Minneapolis / St. Paul Business Journal. Retrieved from http://www.bizjournals.com/twincities/news/2013/04/24/minneapolis-convention-hotel-would.html

Walker, B. (2003, March 5). Convention "headquarters" hotels: Do they generate additional market demand? (Source Strategies, Inc. report to Citizens for a Sound Economy). Retrieved from http://sourcestrategies.org/pdf/ssi_conv_hq_hotels.pdf

\section{Author Biographies}

Robert R. Nelson is Associate Professor and Iimmediate Past Chair of the University of Delaware's Department of Hotel, Restaurant \& Institutional Management. He served as editor-inchief of the Journal of Convention \& Event Tourism from 2007 to 2012. Dr. Nelson's book projects include Current Issues in Convention and Exhibition Facility Development and Developing a Successful Infrastructure for Convention \& Event Tourism.

Jan A. deRoos is HVS Professor of Hotel Finance and Real Estate at the Cornell University School of Hotel Administration, where he has taught since 1988. He has devoted his career to teaching and research related to hospitality real estate, with a focus on the valuation, financing, development, and control of lodging, timeshare, and restaurant assets. His book on hotel management agreements, co-authored with the late James Eyster, is the seminal academic publication on the topic.

Andrey D. Ukhov, Ph.D., is an Assistant Professor of Finance at the School of Hotel Adinistration, Cornell University. His research interests are theoretical and empirical asset pricing. 